\title{
Effects of phosphorus availability on plant growth and soil nutrient status in the rice/soybean rotation system on newly cultivated acidic soils
}

\author{
Laye Djouba Conde ${ }^{1,2}$, Zhijian Chen ${ }^{1}$, Hongkao Chen ${ }^{1}$, Hong Liao ${ }^{1}$ \\ ${ }^{1}$ State Key Laboratory for Conservation and Utilization of Subtropical Agro-Bioresources, Root Biology Center, South China Agricultural \\ University, Guangzhou, 510642, People's Republic of China \\ ${ }^{2}$ National Department of Agriculture, Ministry of Agriculture and Livestock, Conakry BP: 576, Republic of Guinea
}

Email address:

hliao@scau.edu.cn (Hong Liao), ladjoc@hotmail.com (L. D. Conde)

\section{To cite this article:}

Laye Djouba Conde, Zhijian Chen, Hongkao Chen, Hong Liao. Effects of Phosphorus Availability on Plant Growth and Soil Nutrient Status in the Rice/Soybean Rotation System on Newly Cultivated Acidic Soils. American Journal of Agriculture and Forestry.

Vol. 2, No. 6, 2014, pp. 309-316. doi: 10.11648/j.ajaf.20140206.23

\begin{abstract}
Acid soils are worldwide spread, where low phosphorus (P) availability is considered as the major limiting constraint for crop growth, particularly on the newly cultivated acidic soils. Traditionally, the rotation system of rice with leguminous crops has been often used on acid soils. However, little is known about how P availability affects this traditional rotation system on acid soils. In the present study, two years of soil pot experiments had been done using rice (Oryza sativa L.) as the first crop and soybean (Glycine Max L.) as the second crop. The results showed that rice growth were significantly affected by $\mathrm{P}$ fertilization on acid soils. Sufficient $\mathrm{P}$ application increased plant height, shoot biomass, tiller number, and panicle dry weight compared to that of no P fertilization in both two years' studies. The growth of following crop soybean was also influenced by $\mathrm{P}$ supply, and the $\mathrm{P}$ efficient genotype HX1 exhibited more adaptive to low $\mathrm{P}$ than the $\mathrm{P}$ inefficiency genotype BD2, as reflected by better growth of HX1 than BD2. Rhizosphere $\mathrm{pH}$ and soil nutrient status was significantly influenced by the rotation system. An increased tendency of rhizosphere $\mathrm{pH}$ was observed after the growth of rice and soybean. Soil N concentration was significantly increased after planting HX1 but not BD2. Furthermore, rice rotated with HX1 resulted in higher $\mathrm{P}$ fertilizer use efficiency (PFUE). Taken together, we conclude that the rice-soybean rotation with optimal $\mathrm{P}$ supply is a suitable agricultural mode on acid soils, and rotating with the $\mathrm{P}$ efficient soybean genotype could benefit more in soil nutrient status, which might increase the agriculture sustainability on acid soils.
\end{abstract}

Keywords: P Availability, Crop Rotation, P Fertilization, Nutrient Status, Acid Soils

\section{Introduction}

Acid soils $(\mathrm{pH}<5)$ are widely distributed in the world, and over $40 \%$ of the world's arable lands are acidic [1]. In China, there are about 2.1 million ha of acid soils, which mainly existed in South China [2]. Although the abundant rainfall and high temperature make this region beneficial for agricultural production, there are still a lot of limiting factors for crop growth, such as low $\mathrm{pH}$, low cation exchange capacity (CEC) and organic matter, which easily lead to nutrient deficiency and element toxicity, such as phosphorus (P) deficiency and aluminum (Al) toxicity, especially on the newly cultivated acid soils [3]. The newly cultivated acid soils are much severely affected by all above characters and required great amount of fertilizers to maintain or improve crop yield, and thus believed to have significant negative effects on the quality and production of crops on these soils [4]. Therefore, the crop productivity of these soils is generally low, and proper utilization and amelioration for the soil constraints, especially low $\mathrm{P}$ bioavailability, remain a great challenge for agricultural production [5].

Phosphorus is an essential macronutrient for plant growth [6]. Although the total amount of P is high in soils, available $\mathrm{P}$ for plant growth is often limited, especially in acid soils, where $\mathrm{P}$ is easily fixed by soil components into unavailable forms [7]. Low $\mathrm{P}$ availability is a major limiting constraint for crop production on acid soils [8]. In spite of application of $\mathrm{P}$ fertilizer is essential to maintain crop yield, applied $\mathrm{P}$ 
fertilization efficiency is usually low (only 20\%) and readily leading to $\mathrm{P}$ accumulation in soils and resulting in potentially environmental pollution, and thus not economic for agricultural production at developing countries or even at developed countries [9]. Furthermore, $\mathrm{P}$ fertilizers are produced from phosphate rock which is a non-renewable resource, and will be fully consumed within next few decades [10]. Therefore, to improve P fertilizer management as well as to enhance P efficiency in crops is absolutely necessary for environment-friendly agriculture.

Appropriate crop cultivation is absolutely necessary to increase crop biomass and yield, such as rotation and intercropping among various crop species [11]. Crop rotation has been used for thousands of years. Improvements in soil physical properties and soil organic matter including multiple years of sod, pasture, or hay, probably play a beneficial role in rotations [12]. In cereals and legumes rotation system, legumes are considered as the resource of nitrogen $(\mathrm{N})$, since legume nodules have the strongly ability of $\mathrm{N}_{2}$ fixation, and thus increased $\mathrm{N}$ availability to the following crops, which also contributes to increase soil fertility and avoid some diseases proliferation in crops [13,14]. Furthermore, it has been reported that some pre-culture crops, such as rice and wheat, have a potential ability to mobilize insoluble $\mathrm{P}$ from soils and thus make the $\mathrm{P}$ available to the following crop species [15]. Therefore, rice rotated with legumes has been traditionally used for increasing crop yield as well as improving soil fertility.

Rice (Oryza sativa L.) is the world's most important crop and a primary food for half of the world's population [16]. Soybean (Glycine max L.) is the world's foremost provider of protein and oil, which could form symbiosis with rhizobia to form nodule and thus fix atmospheric $\mathrm{N}$ [17]. In this study, pot experiments on rice-soybean rotation were conducted for two years (2009 and 2010) using newly cultivated acid soils at the Ningxi experimental site of South China Agricultural University in Guangdong Province. Rice (Oryza sativa L., var. Hua han xi) was grown as the first crop during the first season (April-August) and then followed by two soybean genotypes (Glycine max L., var. HX1 and BD2) contrasting in $\mathrm{P}$ efficiency in the second season (August-November). Effects of $\mathrm{P}$ availability on the growth of rice and soybean plants as well as soil nutrient status were investigated under greenhouse conditions. The beneficial effects of rice rotating with the $\mathrm{P}$ efficient soybean genotype on soil nutrient status were further discussed.

\section{Materials and Methods}

\subsection{Plants Materials and Growth Conditions}

The rice-soybean rotation experiment had been conducted in 2009 and 2010 in a greenhouse located at the Ningxi experimental site of South China Agricultural University in Guangdong Province, China (22 $\left.{ }^{\circ} 56^{\prime} \mathrm{N}, 1132^{\circ} 57^{\prime} \mathrm{E}\right)$, where the climate is subtropical and the average annual rainfall is about $1200 \mathrm{~mm}$, out of which 70-80\% occurs during May-
October. The soil has developed on a basaltic alluvium of very fine montmorillonite. The textural class of soil is Ultisols, often known as red clay soils (USDA soil taxonomy). Basic soil chemical characteristics as follows: $\mathrm{pH}$, 4.38; organic matter, 0.88\%; available P Bray II method [18], $8.96 \mathrm{mg} \mathrm{P} \mathrm{kg}{ }^{-1}$; available nitrogen $(\mathrm{N}), 19.58 \mathrm{mg} \mathrm{N} \mathrm{kg}^{-1}$; available potassium (K), $64.25 \mathrm{mg} \mathrm{K} \mathrm{kg}^{-1}$.

One rice cultivar (Oryza sativa L., var. Hua Han xi) and two soybean genotypes (Glycine Max L., var. HX1 and BD2) were used in these two years' experiments. Among the two soybean genotypes, HX1 had been previously proved as the P efficient genotype and BD2 as the P inefficient genotype through field screening studies for P efficiency on acid soils [19]. Thirty days old rice seedlings stemming from nurses were transplanted into soil pots as the first crop from April to August. After rice plants harvested, the soil of each pot was separately sifted to eliminate the left roots, and then two soybean genotypes were grown in the same pot with the same soil materials without any fertilization from August to November at the same year.

There were three $\mathrm{P}$ treatments in the experiments, including high $\mathrm{P}\left(200 \mathrm{mg} \mathrm{P}_{2} \mathrm{O}_{5} \mathrm{~kg}^{-1}\right.$ soil added as calcium super phosphate, HP), low $\mathrm{P}\left(100 \mathrm{mg} \mathrm{P}_{2} \mathrm{O}_{5} \mathrm{~kg}^{-1}\right.$ soil added as calcium super phosphate, LP), and non $\mathrm{P}$ (none $\mathrm{P}$ fertilizer added, NP). The P fertilizer was applied to the soil and fully mixed, and then kept under submerged conditions for $1 \mathrm{~d}$ before transplanting. $200 \mathrm{mg} \mathrm{kg}^{-1}$ of $\mathrm{N}$ from urea $\left(\mathrm{CO}\left(\mathrm{NH}_{2}\right)_{2}\right)$ and $200 \mathrm{mg} \mathrm{kg}^{-1}$ of $\mathrm{K}$ from potassium chloride $(\mathrm{KCl})$ were applied for each treatment. All the fertilizers were applied one time as basal fertilizer before rice growth. The same soils with P fertilizers (NP, LP and HP) used for rice plants were maintained for soybean growth without any other fertilization. Each treatment had eight replicates for rice and four replicates for each soybean genotype, and thus there were 24 pots in total in each year. Plastic boxes with $25 \mathrm{~cm} \times 19 \mathrm{~cm}$ and $23 \mathrm{~cm} \times 23 \mathrm{~cm}$ (diameter $\times$ depth) were employed in the pot experiments in 2009 and 2010, respectively. The rice and soybean plants were harvested at $105 \mathrm{~d}$ and $92 \mathrm{~d}$ after $\mathrm{P}$ treatments, respectively. After washing soils away with water, shoot and root samples were collected for further measurements.

\subsection{Determination of Root Growth Parameters and P Content}

Total root length and root surface area were measured using an Epson 1640XL scanner (Epson Corp., Nagano, Japan) and further quantified with the WinRhizo software (Regent Instruments Inc., Sainte-Foy, Canada). After that, shoot and root samples were oven dried at $105^{\circ} \mathrm{C}$ for $30 \mathrm{~min}$ and further dried at $75^{\circ} \mathrm{C}$ for dry weight determination. Then, shoots were ground into powder, and $0.2 \mathrm{~g}$ sample was digested with a mixture of $\mathrm{H}_{2} \mathrm{SO}_{4}-\mathrm{HClO}_{4}$ and total $\mathrm{P}$ content was measured via the phosphorus-molybdate blue color reaction [20]. The root/shoot ratio was determined as dry weight of roots divided by those of shoots. The $\mathrm{P}$ fertilizer use efficiency (PFUE) was calculated according to [21] as follows: 


$$
\text { PFUE }=\frac{P \text { uptake in the fertilized treatment }-\mathrm{P} \text { uptake in the control treatment }}{\text { Amount of } \mathrm{P} \text { applied for the fertilized treatment }} \times 100
$$

Namely P uptake by plants with LP or HP treatment minus those of with NP treatment, and then divided by the amount of P fertilized in soils (LP or HP).

\subsection{Analysis of Soil Nutrient Status}

For determination of N, P and $\mathrm{K}$ content in soils, the soil samples were collected after rice or soybean plants harvested. The soil available $\mathrm{P}$ was extracted by the Bray II method digesting with $25 \mathrm{~mL}$ mixture of $\mathrm{HClO}_{4}-\mathrm{H}_{2} \mathrm{SO}_{4}$ and measured as described above. $\mathrm{N}$ and $\mathrm{K}$ in soils were measured according to [20].

\subsection{Data Analysis}

All the statistical analysis was performed in Microsoft Excel 2003 (Microsoft Company, Redmond, WA, USA) for calculating means and standard errors. Statistical Package for Social Sciences (SPSS 15.0, 2001) was used for ANOVA and multiple comparison analysis.

\section{Results}

\subsection{Rice Growth as Affected by P Availability}

Table 1. Rice growth was affected by $P$ availability in 2009 and 2010.

\begin{tabular}{|c|c|c|c|c|c|}
\hline Year & Treatment & $\begin{array}{l}\text { Plant height } \\
/ \mathrm{cm}_{\text {plant }}{ }^{-1}\end{array}$ & $\begin{array}{l}\text { Shoot biomass } \\
\text { / g (3 plants })^{-1}\end{array}$ & $\begin{array}{l}\text { Tiller number } \\
\text { /\# (3 plants })^{-1}\end{array}$ & $\begin{array}{l}\text { Panicle dry weight } \\
\text { / g (3 plants })^{-1}\end{array}$ \\
\hline \multirow{4}{*}{2009} & NP & $50.87 \pm 13.21 b$ & $7.75 \pm 3.44 b$ & $7.37 \pm 2.32 \mathrm{c}$ & $3.18 \pm 2.55 b$ \\
\hline & LP & $78.75 \pm 6.40 \mathrm{a}$ & $56.53 \pm 17.82 \mathrm{a}$ & $33.87 \pm 5.56 \mathrm{~b}$ & $40.62 \pm 16.24 \mathrm{a}$ \\
\hline & $\mathrm{HP}$ & $82.12 \pm 7.33 a$ & $63.54 \pm 23.17 \mathrm{a}$ & $40.37 \pm 7.76 \mathrm{a}$ & $40.25 \pm 13.47 \mathrm{a}$ \\
\hline & $F$-value & $26.18 * * *$ & $25.57 * * *$ & $75.87 * * *$ & $24.58 * * *$ \\
\hline \multirow{4}{*}{2010} & NP & $83.19 \pm 2.64 c$ & $51.62 \pm 20.94 b$ & $22.13 \pm 3.314 c$ & $25.02 \pm 11.47 \mathrm{~b}$ \\
\hline & LP & $99.75 \pm 3.61 b$ & $61.08 \pm 6.409 b$ & $40.25 \pm 4.13 b$ & $62.17 \pm 14.38 \mathrm{a}$ \\
\hline & $\mathrm{HP}$ & $105.60 \pm 5.04 \mathrm{a}$ & $80.73 \pm 8.05 a$ & $47.38 \pm 7.19 \mathrm{a}$ & $85.60 \pm 18.84 a$ \\
\hline & $F$-value & $71.44 * * *$ & $9.72 * *$ & $51.00 * * *$ & $16.12 * * *$ \\
\hline
\end{tabular}

$\mathrm{HP}\left(200 \mathrm{P}_{2} \mathrm{O}_{5} \mathrm{mg} \mathrm{kg}^{-1}\right)$ and LP $\left(100 \mathrm{P}_{2} \mathrm{O}_{5} \mathrm{mg} \mathrm{kg}^{-1}\right)$ added as calcium super phosphate. NP means none P fertilizer added. All the data are the means of eight replicates with standard error. The same letter in the same column indicated no significant difference between $\mathrm{P}$ treatments at the $P<0.05$ level. $F$-value was calculated by two-way ANOVA. Asterisk indicated significant difference. **: $0.001<P<0.01$; ***: $P<0.001$.

As the first crop in the rice-soybean rotation during April to August in 2009 and 2010, rice growth was significantly affected by $\mathrm{P}$ fertilization $(P<0.05)$ (Table 1). Although similar effects on rice growth were observed between LP and HP treatments, rice growth was enhanced with increasing $\mathrm{P}$ application compared to that of no $\mathrm{P}$ fertilization (NP). For example, with sufficient P supply (HP) in soils in 2009, plant height, shoot biomass, tiller number, and panicle dry weight were significantly increased by $61.43 \%, 719.87 \%, 447.76 \%$ and $165.72 \%$ compared with that in NP conditions, respectively (Table 1). Similarly, increased P supply in 2010 also resulted in dramatically increase in plant growth. Plant height, tiller number, shoot biomass and panicle dry weight were $26.93 \%, 56.39 \%, 114.09 \%$ and $242.12 \%$ higher in HP than that in NP conditions, respectively (Table 1). Furthermore, we also observed that plant growth of all the above parameters in 2010 were better than that in 2009, which probably due to soil nutrient status in 2010 was more fertile than that in 2009.

\subsection{Soybean Growth as Affected by P Availability}

After rice plants harvested, two soybean genotypes contrasting in $\mathrm{P}$ efficiency were separately cultured in the same soils from August to November in the same year without any fertilization. For the $\mathrm{P}$ inefficient soybean genotype BD2 in 2009, significantly higher plant height $\left(37.75 \mathrm{~cm}\right.$ plant $\left.{ }^{-1}\right)$, plant biomass $\left(9.65 \mathrm{~g}(3 \text { plants })^{-1}\right)$ and root/shoot ratio $\left(0.95 \mathrm{~g}(3 \text { plants })^{-1}\right)$ were observed at HP treatment, but the above parameters were not different between LP and NP treatments (Table 2). Furthermore, P supply significantly affected $\mathrm{BD} 2$ root growth, including total root length and root surface area. The longest root length was observed at HP treatment followed by LP treatment, which was $326.27 \%$ and $204.71 \%$ higher than those at NP treatment. Similar response was also observed in root surface area, HP had the highest value of root surface area, followed by LP and NP (Table 2).

For the P efficient soybean genotype HX1 in 2009, the growth of HX1 was also affected by P fertilization. As shown in Table 3, increasing P supply (LP and HP) enhanced the growth of HX1, especially under HP conditions, which plant height and plant biomass was $51.06 \%$ and $231.63 \%$ higher than that in NP treatment, respectively. Furthermore, growth of HX1 roots was also influenced by P supply. The root/shoot ratio, total root length and root surface area under HP were $526 \%, 132.19 \%$ and $409.04 \%$ higher than that in NP conditions, respectively (Table 3 ).

Consistent to the results from 2009, most of the growth parameters of $\mathrm{BD} 2$ were increased with increasing $\mathrm{P}$ fertilization in 2010, especially in HP conditions (Table 2). For HX1, plant height, plant biomass and root surface area were increased with increasing $\mathrm{P}$ fertilization, whereas root/shoot ratio, total root length were similar within $\mathrm{P}$ treatments in 2010 (Table 3). Furthermore, we also found that 
most of the growth parameters in HX1 were higher than those in BD2 among different $\mathrm{P}$ treatments, especially in 2010 (Tables 2 and 3), confirmed that the P efficient soybean genotype HX1 have a higher $\mathrm{P}$ acquisition and/or utilization efficiency than BD2.

Table 2. Soybean (BD2) growth was affected by P availability in 2009 and 2010.

\begin{tabular}{|c|c|c|c|c|c|c|}
\hline Year & Treatment & Plant height $/ \mathrm{cm}$ plant $^{-1}$ & 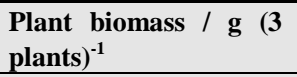 & Root/Shoot ratio & RL / cm (3 plants) ${ }^{-1}$ & $\mathrm{RSA} / \mathrm{cm}^{2}\left(3\right.$ plants $\left.^{-1}\right)$ \\
\hline \multirow{4}{*}{2009} & NP & $26.00 \pm 1.63 b$ & $2.01 \pm 0.43 b$ & $0.72 \pm 0.61 b$ & $61.55 \pm 8.72 \mathrm{c}$ & $3.22 \pm 0.53 c$ \\
\hline & LP & $30.00 \pm 2.94 b$ & $4.58 \pm 1.25 b$ & $0.83 \pm 0.51 b$ & $126.00 \pm 47.97 b$ & $5.92 \pm 1.98 \mathrm{~b}$ \\
\hline & $\mathrm{HP}$ & $37.75 \pm 6.55 a$ & $9.65 \pm 5.21 \mathrm{a}$ & $0.95 \pm 0.23 a$ & $200.82 \pm 38.10 \mathrm{a}$ & $9.27 \pm 1.50 \mathrm{a}$ \\
\hline & $F$-value & $7.89 *$ & $7.28 *$ & $6.34 *$ & $15.22 * *$ & $17.02 * *$ \\
\hline \multirow{4}{*}{2010} & NP & $21.00 \pm 2.16 \mathrm{c}$ & $2.66 \pm 1.18 \mathrm{c}$ & $0.59 \pm 0.32 b$ & $487.25 \pm 207.91 b$ & $64.50 \pm 14.05 b$ \\
\hline & LP & $24.00 \pm 1.63 b$ & $6.97 \pm 2.65 b$ & $0.62 \pm 0.51 b$ & $695.50 \pm 111.21 \mathrm{~b}$ & $77.95 \pm 13.56 \mathrm{~b}$ \\
\hline & $\mathrm{HP}$ & $28.25 \pm 1.70 \mathrm{a}$ & $10.53 \pm 6.43 \mathrm{a}$ & $0.96 \pm 0.80 \mathrm{a}$ & $956.75 \pm 328.28 \mathrm{a}$ & $141.47 \pm 35.29 \mathrm{a}$ \\
\hline & $F$-value & $15.53^{* *}$ & $13.62 * *$ & $7.59 *$ & $4.06^{*}$ & $12.46^{* *}$ \\
\hline
\end{tabular}

$\mathrm{HP}\left(200 \mathrm{P}_{2} \mathrm{O}_{5} \mathrm{mg} \mathrm{kg}^{-1}\right)$ and $\mathrm{LP}\left(100 \mathrm{P}_{2} \mathrm{O}_{5} \mathrm{mg} \mathrm{kg}^{-1}\right)$ added as calcium super phosphate. NP means none P fertilizer added. RL: Root length. RSA: Root surface area. All the data are the means of four replicates with standard error. The same letter in the same column indicated no significant difference between $P$ treatments at the $P<0.05$ level. $F$-value was calculated by two-way ANOVA. Asterisk indicated significant difference. $*: 0.01<P<0.05$; $* *: 0.001<P<0.01$.

Table 3. Soybean (HX1) growth was affected by P availability in 2009 and 2010.

\begin{tabular}{|c|c|c|c|c|c|c|}
\hline Year & Treatment & $\begin{array}{l}\text { Plant height } \\
/ \mathrm{cm}_{\text {plant }}{ }^{-1}\end{array}$ & $\begin{array}{l}\text { Plant biomass } \\
\text { / g (3 plants })^{-1}\end{array}$ & Root/Shoot ratio & $\begin{array}{l}\text { RL } \\
/ \text { cm }(3 \text { plants })^{-1}\end{array}$ & $\begin{array}{l}\text { RSA } \\
/ \mathrm{cm}^{2}(3 \text { plants })^{-1}\end{array}$ \\
\hline \multirow{4}{*}{2009} & NP & $25.32 \pm 5.06 \mathrm{~b}$ & $3.78 \pm 1.52 \mathrm{~b}$ & $0.13 \pm 0.08 \mathrm{a}$ & $143.20 \pm 65.20 \mathrm{~b}$ & $5.75 \pm 2.04 c$ \\
\hline & LP & $34.00 \pm 3.16 \mathrm{a}$ & $5.83 \pm 02.18 b$ & $0.25 \pm 0.12 \mathrm{a}$ & $223.05 \pm 84.5 \mathrm{ba}$ & $15.37 \pm 2.13 b$ \\
\hline & $\mathrm{HP}$ & $38.25 \pm 2.21 \mathrm{a}$ & $11.38 \pm 4.21 \mathrm{a}$ & $0.94 \pm 0.23 b$ & $332.50 \pm 62.34 \mathrm{a}$ & $29.27 \pm 2.51 \mathrm{a}$ \\
\hline & $F$-value & $12.82 * *$ & $18.49 * *$ & $5.20 *$ & $7.09 *$ & $111.29 * * *$ \\
\hline \multirow{4}{*}{2010} & NP & $30.50 \pm 1.29 b$ & $8.92 \pm 3.14 c$ & $0.39 \pm 0.17 \mathrm{a}$ & $521.00 \pm 169.97 \mathrm{a}$ & $71.30 \pm 29.85 b$ \\
\hline & LP & $40.50 \pm 3.69 a$ & $13.66 \pm 5.25 b$ & $0.33 \pm 0.11 b$ & $988.42 \pm 568.90 \mathrm{a}$ & $140.32 \pm 70.58 \mathrm{a}$ \\
\hline & HP & $42.25 \pm 3.30 \mathrm{a}$ & $23.97 \pm 4.37 \mathrm{a}$ & $0.30 \pm 0.09 b$ & $1168.83 \pm 349.49 a$ & $241.02 \pm 86.34 \mathrm{a}$ \\
\hline & $F$-value & $18.37 * *$ & $26.22 * * *$ & $5.20 *$ & $2.82 \mathrm{~ns}$ & $6.55^{* *}$ \\
\hline
\end{tabular}

$\mathrm{HP}\left(200 \mathrm{P}_{2} \mathrm{O}_{5} \mathrm{mg} \mathrm{kg}^{-1}\right)$ and LP (100 $\left.\mathrm{P}_{2} \mathrm{O}_{5} \mathrm{mg} \mathrm{kg}^{-1}\right)$ added as calcium super phosphate. NP means none P fertilizer added. RL: Root length. RSA: Root surface area. All the data are the means of four replicates with standard error. The same letters in the same column indicate no significant difference between $P$ treatments at the $P<0.05$ level. $F$-value was calculated by two-way ANOVA. Asterisk indicated significant difference. ${ }^{*}: 0.01<P<0.05 ; * *: 0.001<P<0.01$;

***: $P<0.001$. ns, indicated no significant difference at the $P<0.05$ level.

\subsection{Effects of P Availability on Soil pH and Nutrient Status in the Rice-Soybean Rotation System}

We further investigated the changes of $\mathrm{pH}$ and nutrient status in rhizosphere after rice and soybean growth at three $\mathrm{P}$ levels. As shown in Table 4, the initial $\mathrm{pH}$ of the newly cultivated acid soils was 4.38 and 4.50 in 2009 and 2010, respectively. An increased tendency of rhizosphere $\mathrm{pH}$ was observed after the growth of rice and soybean at all P levels, especially in 2010. Furthermore, rhizosphere $\mathrm{pH}$ was higher after growth of HX1 as compared to BD2 (Table 4). The nutrient status in rhizosphere showed that $\mathrm{N}, \mathrm{P}$ and $\mathrm{K}$ concentrations in soils were decreased after rice growth at three $\mathrm{P}$ levels, and the three tested nutrient concentrations were decreased when the P level was increased both in 2009 and 2010 (Table 5). Similarly, P and K concentration in soils were also decreased after BD2 and HX1 growth in both two years (Table 5). Interestingly, $\mathrm{N}$ concentration in soils was increased after soybean (both BD2 and HX1) growth both in 2009 and 2010. For example, after the growth of the $\mathrm{P}$ efficient soybean genotype $\mathrm{HX} 1, \mathrm{~N}$ concentration in soils were $121.16 \%, 173.48 \%$ and $101.29 \%$ increasing at NP, LP and HP treatments, respectively (Table 5), which was probably attributed to the strong symbiotic $\mathrm{N}$ fixation ability of soybean plants to increase $\mathrm{N}$ concentration in soils.

Table 4. Changes of $\mathrm{pH}$ in rhizosphere of rice and soybean plants in 2009 and 2010.

\begin{tabular}{|c|c|c|c|c|c|}
\hline \multirow{2}{*}{ Year } & \multirow{2}{*}{ Treatment } & \multirow{2}{*}{ Before planting } & \multirow{2}{*}{ After rice } & \multicolumn{2}{|c|}{ After soybean } \\
\hline & & & & BD2 & HX1 \\
\hline \multirow{4}{*}{2009} & NP & \multirow{4}{*}{4.38} & $4.45 \pm 0.09 a$ & $5.19 \pm 0.04 a$ & $5.30 \pm 0.06 a$ \\
\hline & LP & & $4.56 \pm 0.10 \mathrm{a}$ & $5.20 \pm 0.05 a$ & $5.20 \pm 0.05 a$ \\
\hline & $\mathrm{HP}$ & & $4.62 \pm 0.10 \mathrm{a}$ & $5.21 \pm 0.05 a$ & $5.25 \pm 0.03 a$ \\
\hline & $F$-value & & $2.01 \mathrm{~ns}$ & $1.21 \mathrm{~ns}$ & $3.11 \mathrm{~ns}$ \\
\hline \multirow{4}{*}{2010} & $\mathrm{NP}$ & \multirow{4}{*}{4.50} & $5.29 \pm 0.17 a$ & $5.84 \pm 0.07 a$ & $5.95 \pm 0.08 \mathrm{a}$ \\
\hline & LP & & $5.30 \pm 0.22 \mathrm{a}$ & $6.12 \pm 0.15 a$ & $6.17 \pm 0.16 \mathrm{a}$ \\
\hline & $\mathrm{HP}$ & & $5.31 \pm 0.24 a$ & $6.25 \pm 0.16 \mathrm{a}$ & $6.33 \pm 0.19 a$ \\
\hline & $F$-value & & $1.51 \mathrm{~ns}$ & $2.81 \mathrm{~ns}$ & $2.91 \mathrm{~ns}$ \\
\hline
\end{tabular}

$\mathrm{HP}\left(200 \mathrm{P}_{2} \mathrm{O}_{5} \mathrm{mg} \mathrm{kg}^{-1}\right)$ and $\mathrm{LP}\left(100 \mathrm{P}_{2} \mathrm{O}_{5} \mathrm{mg} \mathrm{kg}^{-1}\right)$ added as calcium super phosphate. NP means none P fertilizer added. All the data are the means of four replicates with standard error. The same letters in the same column indicate no significant difference between $\mathrm{P}$ treatments at the $P<0.05$ level. $F$-value was calculated by two-way ANOVA. ns, indicated no significant difference at the $P<0.05$ level. 
Table 5. Changes of nutrient status in rhizosphere of rice and soybean plants in 2009 and 2010.

\begin{tabular}{|c|c|c|c|c|c|c|c|c|c|c|}
\hline \multirow{2}{*}{ Year } & \multirow{2}{*}{ Nutrient } & \multicolumn{3}{|l|}{ Rice } & \multicolumn{3}{|l|}{ BD2 } & \multicolumn{3}{|l|}{ HX1 } \\
\hline & & NP & LP & HP & NP & LP & HP & NP & LP & HP \\
\hline \multirow{4}{*}{2009} & $\mathrm{~N}$ & $-68 \%$ & $-82.89 \%$ & $-80.18 \%$ & $+121.16 \%$ & $+173.48 \%$ & $+101.29 \%$ & $+25.84 \%$ & $+42.45 \%$ & $+7.3 \%$ \\
\hline & $\mathrm{P}$ & $-5.58 \%$ & $-72.29 \%$ & $-64.82 \%$ & $-7.03 \%$ & $-16.95 \%$ & $-40.28 \%$ & $-42.41 \%$ & $-14.40 \%$ & $-21.32 \%$ \\
\hline & K & $-38.66 \%$ & $-47.76 \%$ & $-61.33 \%$ & $-47.76 \%$ & $-61.33 \%$ & $-39.42 \%$ & $-47.32 \%$ & $-59.23 \%$ & $-68.20 \%$ \\
\hline & $\mathrm{N}$ & $-62.21 \%$ & $-83.55 \%$ & $-83.09 \%$ & $+78.72 \%$ & $+172.91 \%$ & $+140.54 \%$ & $+84.47 \%$ & $+180.90 \%$ & $+150.61 \%$ \\
\hline \multirow[t]{2}{*}{2010} & $\mathrm{P}$ & $-52.00 \%$ & $-87.79 \%$ & $-88.56 \%$ & $-27.80 \%$ & $-44.61 \%$ & $-44.33 \%$ & $-18.25 \%$ & $-59.95 \%$ & $-53.44 \%$ \\
\hline & $\mathrm{K}$ & $-30.51 \%$ & $-45.40 \%$ & $-65.10 \%$ & $-16.95 \%$ & $-9.98 \%$ & $-4.09 \%$ & $-33.94 \%$ & $-25.94 \%$ & $-3.74 \%$ \\
\hline
\end{tabular}

$\mathrm{HP}\left(200 \mathrm{P}_{2} \mathrm{O}_{5} \mathrm{mg} \mathrm{kg}^{-1}\right)$ and $\mathrm{LP}\left(100 \mathrm{P}_{2} \mathrm{O}_{5} \mathrm{mg} \mathrm{kg}^{-1}\right)$ added as calcium super phosphate. NP means none P fertilizer added. ' + ' means increasing rate between soil nutrient concentration before rice or soybean and after rice/or soybean; '-' means decreasing rate between soil nutrient concentration before rice/or soybean and after rice/or soybean.

\subsection{P Fertilizer Use Efficiency (PFUE) in Rice-Soybean Rotation on Acid Soils}

The results showed that the PFUE for rice, HX1 and BD2 under HP conditions were higher than that in LP conditions in 2009 (Figure 1A), and the highest PFUE was observed in rice $(42.31 \%)$ followed by $\mathrm{HX} 1(4.89 \%)$ and BD2 (3.94\%) under both LP and HP conditions in 2009 (Figure 1A). Moreover, the total PFUE for rice/HX1 rotation were $46.53 \%$ and $67.42 \%$, which were higher than that for rice/BD2 rotation $(37.78 \%$ and $46.68 \%$ ) in LP and HP treatments in 2009, respectively. However, in contrast to 2009, PFUE for rice under LP conditions was significantly higher than that in HP conditions in 2010, which resulted in lower total PFUE for both rice/HX1 and rice/BD2 rotation under HP conditions compared to LP treatment in 2010 (Figure 1B). These results indicated that rice rotated with the $\mathrm{P}$ efficient soybean genotype HX1 had higher PFUE, which is better for development of sustainable agriculture through reduced $\mathrm{P}$ fertilization.

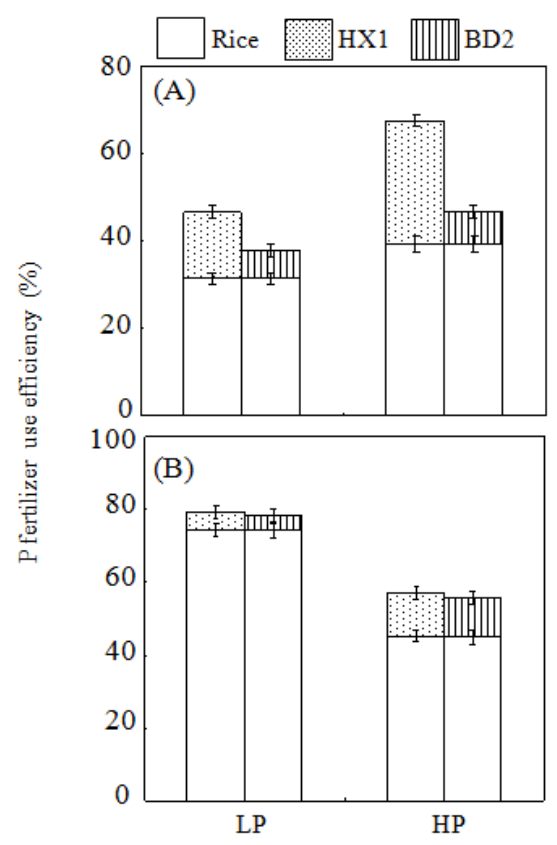

Figure 1. Phosphorus fertilizer use efficiency (PFUE) at rice-soybean rotation. (A) PFUE in 2009. (B) PFUE in 2010. $\mathrm{HP}\left(200 \mathrm{P}_{2} \mathrm{O}_{5} \mathrm{mg} \mathrm{kg}^{-1}\right)$ and LP (100 $\left.\mathrm{P}_{2} \mathrm{O}_{5} \mathrm{mg} \mathrm{kg}^{-1}\right)$ added as calcium super phosphate. Each bar represents the means of eight replicates for rice and four replicates for soybean with standard error.

\section{Discussion}

The newly cultivated acidic soils are not suitable for crop growth because of many poor soil properties, which make it unproductive for agricultural development [20]. Low $\mathrm{pH}$ and low $\mathrm{P}$ availability are consider as the two coexisted important limiting factors for crop growth and productivity on acid soils. It has been reported that rice growth in newly cultivated acidic soils was seriously influenced and thus decreased rice productivity [22, 23]. The growth of other crop species, such as cotton and maize, was also influenced attributed to adverse soil fertility and the proliferation of plant disease [24]. Until now, diverse appropriate crop systems were improved by farmers to adapt to the infertility of newly cultivated acid soils, such as intercropping and crop rotation [25].

Crop rotation system is an effective approach to improve soil fertility and further support crop growth [26]. Rotations of cereals with legumes or waterlogged crop with legumes have positive effects on improvement in the soil physical properties [27]. Increased organic matter or plant residues returned to soils after the first cereal crop were considered as a great advantage for the soil fertility that contributed more benefits to the following crop under crop rotation system [28]

It has been demonstrated that rice and soybean rotation could increase rhizosphere $\mathrm{pH}$ or organic matter, which subsequently affect the growth and activity of microorganisms, and thus benefit for nutrient cycling processes in soils [29]. Presently, our results showed that after both rice and soybean growth, $\mathrm{pH}$ of the newly cultivated acidic soils was increased about 1 unit compared to that before crop planting, especially in 2010 (Table 4), which might benefit in improvement of soil quality and growth of the following crop. Consistently, it has been also revealed that soil $\mathrm{pH}$ was also increased in wheat/common bean, and maize/faba bean rotation system [30, 31]. Based on the $\mathrm{pH}$ changes in the 10 years' soybean and mungbeanbased rotation systems, researchers found that rotation increased up to $1 \mathrm{pH}$ unit in these crop systems [32]. The near neutral $\mathrm{pH}$ probably resulted in maximum dissolution of $\mathrm{P}$ from $\mathrm{Fe}$ and $\mathrm{Al}$ complexes [33]. Additionally, in the cereal legume rotation system, legumes are prone to improve soil microbial activity, and fertility properties through increased water holding capacity, soil organic $\mathrm{C}$ and $\mathrm{N}$ content, which benefit for the next crop growth [34]. Therefore, rice and 
soybean rotation could be one of the important approaches to improve crop production and maintain soil fertility.

In this study, after rice harvested, the concentration of $\mathrm{N}, \mathrm{P}$ and $\mathrm{K}$ in the soil was decreased significantly as compared to soil nutrient status before rice planting (Table 5). This showed that rice plants took up significant amount of $\mathrm{N}, \mathrm{P}$ and $\mathrm{K}$ from the soil for its proper and vigorous growth. Similar effects were also found in maize and wheat that cereal crops have to absorb adequate nutrients from soils in order to meet the demand of shoot and root growth, and thus only a few contribution to improve soil fertility $[35,36]$. In contrast, $\mathrm{N}$ concentration in the soils was significantly increased after soybean growth, especially under LP application, as compared to soils nutrient conditions before soybean planting, while the concentration of $\mathrm{P}$ and $\mathrm{K}$ decreased significantly as compared in the soils before soybean planting (Table 5). Similar results have been reported that legume crops have positive effects on nutrient status, especially on $\mathrm{N}$ and $\mathrm{P}$ status [37]. For example, it have been reported that legume corps with the ability of symbiotic $\mathrm{N}_{2}$ fixation in nodules could lead to significantly increase in the available soil $\mathrm{N}$, and thus increased $\mathrm{N}$ availability for the cereal crops in the legume/cereal rotation system [38]. Thus, in our rice and soybean rotation, soybean plants play an important role in increasing the $\mathrm{N}$ status in soils, which may be further increased the fertility of soils.

Phosphorus fertilizer use efficiency (PFUE) is a parameter that reflected the crop capacity to take up available $\mathrm{P}$ from rhizosphere [39]. In this study, we found that PFUE of the $\mathrm{P}$ efficient soybean genotype HX1 was higher than that of the $\mathrm{P}$ inefficient genotype BD2, especially in 2009 (Figure 1A). It has been demonstrated that crops with higher $\mathrm{P}$ efficiency exhibited higher PFUE in soils, such as wheat, fafa bean, chickpea and rapeseed [40]. Root architecture was closely related to $\mathrm{P}$ efficiency in soybean [17]. Root architecture determines the distribution of the whole root system in the different soil layers hence may affect soil exploration and exploitation of nutrients (especially for nutrients with low mobility, such as P [41, 42]. Additionally, crops with suitable root morphology probably modified rhizosphere $\mathrm{pH}$ and exudates organic acids into rhizosphere, and thereby increased soil P availability [43]. In this study, HX1 exhibited appropriate root/shoot ratio, root length and root surface area in all $\mathrm{P}$ supply conditions (Table 3), which probably helps its root system to acquire more $\mathrm{P}$ than BD2. Similar response has been previously reported in wheat [44] and rice [45], where $\mathrm{P}$ efficient genotypes highly facilitated biomass accumulation, root growth and plant $\mathrm{P}$ content. Therefore, $\mathrm{P}$ efficient genotype HX1 with appropriate root morphology was probably able to mobilize $\mathrm{P}$ from poorly soluble sources or to take up the available $\mathrm{P}$ in soil solution, and thus increased the PFUE with rice rotation on acid soils.

\section{Conclusions}

Rice/legume rotation was significantly influenced by $\mathrm{P}$ availability on the newly cultivated acidic soils. Sufficient $\mathrm{P}$ application promoted rice growth. The growth of following crop soybean was also influenced by $\mathrm{P}$ supply, and the $\mathrm{P}$ efficient genotype HX1 exhibited more adaptive to low $\mathrm{P}$ than the $\mathrm{P}$ inefficiency genotype BD2. Furthermore, rice rotated with $\mathrm{HX} 1$ resulted in higher PFUE probably attributed to fine root system to acquire more P. Taken together, rice-soybean rotation with optimal $\mathrm{P}$ supply is a suitable agricultural mode on acid soils, and rotating with the $\mathrm{P}$ efficient soybean genotype could benefit more in soil nutrient status, and thereby increase the agriculture sustainability on acid soils.

\section{Acknowledgments}

This work was funded by the grant of National Key Basic Research Special Funds of China (2011CB100301) and National Natural Science Foundation of China (No. 31025022).

\section{References}

[1] L.V. Kochian, O.A. Hoekenga, and M.A. Piñeros. How do crop plants tolerate acid soils? mechanisms of aluminum tolerance and phosphorus efficiency. Ann. Rev. Plant Biol. 55: 459-493, 2004.

[2] D.Q. Feng, Z.D. Chen, X.S. Huang, and L.H. Tang. Utilization of quality forage as fish fodder in the mountainous red soil area of south China. Pratacultural Sci. 23:57-60, 2006.

[3] H.M. Zhang, B.R. Wang, M.G. Xu, and T.L. Fan. Crop yield and soil responses to long-term fertilization on a red soil in Southern China. Pedosphere 19:199-207, 2009.

[4] N.K. Fageria, and V.C. Baligar. Fertility management of tropical acid soil for sustainable crop production. In: Rengel, Z., ed. Handbook of soil acidity. New York, Marcel Dekker, p. 359-385, 2003.

[5] Y. He, H. Lian, and X. Yan. Localized supply of phosphorus induces root morphological and architectural changes of rice in split and stratified soil cultures. Plant Soil 248:247-256, 2003.

[6] K.G. Raghothama and A.S. Karthikeyan. Phosphate acquisition. Plant Soil 274:37-49, 2005.

[7] F. Aref. Influence of zinc and boron nutrition on copper, manganese and iron concentrations in maize leaf. Aust. J. Basic Appl. Sci. 5:52-62, 2011.

[8] X.R. Wang, J.B. Shen, and H. Liao. Acquisition or utilization, which is more critical for enhancing phosphorus efficiency in modern crops? Plant Sci. 179:302-306, 2010.

[9] X.T. Ju, C.L. Kou, P. Christie, Z.X. Dou, and F.S. Zhang. Changes in the soil environment from excessive application of fertilizers and manures to two contrasting intensive cropping systems on the North China Plain. Environ. Pollut. 145:497506, 2007.

[10] W.M. Stewart, L.L. Hammond, and S.J.V. Kauwenbergh. Phosphorus as a natural resource. Phosphorus: agriculture and the environment. P 3-22, 2005. 
[11] C.L.A. Asadu, S.C. Obasi, A.G.O. Dixon, N. Ugele, and G.U. Chibuike. Soil fertility recovery in a cleared forestland cultivated and fallowed for seven years. J. Agri. Biodivers. Res. 25: 110-116, 2013.

[12] D.G. Bullock. Crop rotation. Crit. Rev. Plant Sci. 11:309-326, 1992.

[13] C.E. Ariel, A.E. Ostolaza, E.B. Giardina, and L. Giuffré. Effects of two plant arrangements in corn (Zea Mays L.) and soybean (Glycine Max L. Merrill) intercropping on soil nitrogen and phosphorus status and growth of component crops at an Argentinean argiudoll. Am. J. Agr. Forest. 1:22-31, 2013.

[14] J. Ehrmann, and R. Karl. Plant: soil interactions in temperate multi-cropping production systems. Plant Soil 376:1-29, 2013.

[15] H.G. Li, J.B. Shen, F.S. Zhang, P. Marschner, G. Cawthray, and Z. Rengel. Phosphorus uptake and rhizosphere properties of intercropped and monocropped maize, faba bean, and white lupin in acidic soil. Biol. Fert. Soils 46:79-91, 2010.

[16] N.G. Dowling, S.M. Greenfield, and K.S. Fischerf. Pacific basin study center sustainability of rice in the global food system. Pacific Basin Study Center, Los Banos, Philippines, International Rice Research Institute, 1998.

[17] H. Fujikake, H. Yashima, T. Sato, N. Ohtake, K. Sueyoshi, and T. Ohyama,. Rapid and reversible nitrate inhibition of nodule growth and $\mathrm{N}$ fixation activity in soybean (Glycine Max L. Merr). Soil Sci. Plant Nutr. 48:211-217, 2002.

[18] Bray, R. H., and L. T. Kurtz. 1945. Determination of total organic and available forms of phosphorus in soils. Soil Sci. 59: 39-45.

[19] J. Zhao, J.B Fu, H. Liao, Y. He, H. Nian, Y.M. Hu, L.J. Qiu, Y.S. Dong, and X.L. Yan. Characterization of root architecture in an applied core collection for phosphorus efficiency of soybean germplasm. Chinese Sci. Bull. 49:1611-1620, 2004.

[20] X. Gao, X. Lu, M. Wu, H. Zhang, R. Pan, T. Jian, L. Xian, and H. Liao. Co-Inoculation with rhizobia and AMF inhibited soybean red crown rot: From field study to plant defense-related gene expression analysis. PLoS ONE 7(3):e33977, 2012.

[21] J.M. Mohammad, A. Hammouri, and A.E Ferdows. Phosphorus fertigation and preplant conventional soil application of drip irrigated summer squash. J. Agron. 3:162-169, 2004.

[22] P. Gruhn, F. Goletti, and M. Yudelman. Integrated nutrient management, soil fertility, and sustainable agriculture: current issues and future challenges. International Food Policy Research Institute, Washington, D.C., p. 31, 2000.

[23] T.D. Khanh, M.I. Chung, T.D. Xuan, and S. Tawata. The exploitation of crop allelopathy in sustainable agricultural production. J. Agron. Crop Sci. 191:172-184, 2005.

[24] A.S. Lithourgidis, C.A. Damalas, and A.A. Gagianas. Longterm yield patterns for continuous winter wheat cropping in northern Greece. Eur. J. Agron. 25:208-214, 2006.

[25] N.K. Fageria, O.P. Morais, and V.C. Baligar. Response of rice cultivars to phosphorus supply on oxisol. Fert. Res. 16:195206, 1988.

[26] D. Tilman, K.G. Cassman, P.A. Matson, R. Naylor, and S. Polasky. Agricultural sustainability and intensive production practices. Nature 418:671-677, 2002.
[27] A.G. Good, and H.B. Perrin. Fertilizing nature: a tragedy of excess in the common. PLoS Biol. 9:e1001124, 2011.

[28] J. Peigné, B.C. Ball, J. Roger-Estrade, and C. David1. Is conservation tillage suitable for organic farming? A review. Soil Use Manage. 23:129-144, 2007.

[29] D.L. Karlen, G.E. Varvel, D.G. Bullock, and R.M. Cruse. Crop rotations for the 21st century. Adv. Agron. 53:1-45, 1994.

[30] M.J. Brimecombe, F.A. DeLel, and J.M. Lynch. The effect of root exudates on rhizosphere microbil populations. In: Pinton R, Varanini Z, and Nannipieri P. Ed. The rhizosphere biochemistry and organic substances at the soil-plant Interface. Marcel Dekker, New York, p. 95-140, 2001.

[31] E. Zagal, C. Munoz, M. Quiroz, and C. Cordova. Sensitivity of early indicators for evaluating quality changes in soil organic matter. Geoderma 151:191-198, 2009.

[32] R. Chintala, M.M. Louis, and B.B. William. Effect of soil water and nutrients on productivity of Kentucky bluegrass system in acidic soils. J. Plant Nutr. 35:288-303, 2012.

[33] Y. Imai, S. Miyake, D.A. Hughes, and M. Yamamoto. Identification of a GTPase-activating protein homolog in Schizosaccharomyces pombe. Mol. Cell Biol. 11:3088-3094, 1991.

[34] G.V.N. Powell, and RD Bjork. Implications of altitudinal migration for conservation strategies to protect tropical biodiversity: a case study of the Quetzal Pharomachrus mocinno at Monteverde, Costa Rica. Bird Conserv. Int. 4:243-255, 1994.

[35] V.O. Biederbeck, H.H. Janzen, C.A. Campbell, and R.P. Zentner. Labile soil organic matter as influenced by cropping practices in an arid environment. Soil Biol. Biochem. 26:1647-1656, 1994.

[36] C.A. Grant, D.N. Flaten, D.J. Tomasiewicz, and S.C. Sheppard. The importance of early season phosphorus nutrition. Can. J. Plant Sci. 81:211-224, 2001.

[37] Z.H. Wang, S.X. Li, and S Malhi. Effects of fertilization and other agronomic measures on nutritional quality of crops. J. Sci. Food Agr. 88:7-23, 2008.

[38] P. Jeffries, S. Gianinazzi, S. Perotto, K. Turnau, and J.M. Barea. The contribution of arbuscular mycorrhizal fungi in sustainable maintenance of plant health and soil fertility. Biol. Fert. Soils 37:1-16, 2003.

[39] M.J. Unkovich, J.S. Pate, and P. Sanford. Nitrogen fixation by annual legumes in Australian Mediterranean agriculture. Aust. J. Agric. Res. 48:267-93, 1997.

[40] V.V. Shenoy, and G.M. Kalagudi. Enhancing plant phosphorus use efficiency for sustainable cropping. Biotechnol. Adv. 23:501-513, 2005.

[41] E.S. Jensen, B.P. Mark, and H.N. Henrik. Faba bean in cropping systems. Field Crops Res. 115:203-216, 2010.

[42] J. P. Lynch. Root architecture and plant productivity. Plant Physiol. 109:7-13, 1995.

[43] X.L. Yan, H. Liao, and Z.Y. Ge. Root architectural characteristics and phosphorus acquisition efficiency in plants. Chinese Bull. Bot. 17:511-519, 2001.

[44] W.J. Horst, M. Abdou, and F. Wiesler. Genotypic differences in phosphorus efficiency of wheat. Plant Soil 155:293-296, 1993. 
[45] Y.Y. Sui, X.G. Jiao, and X.Y. Zhang. Research on the integrated assessment of black soil fertility in farmland. Soils Fert. 5:46-48, 2005. 